\title{
Impact of Internet plus to China Economy Development
}

\author{
Zhen Zhao1, Wei Xiong1, Jingxuan Fang2 \\ ${ }^{1}$ International Business School, University of International Business and Economics, Beijing, China \\ ${ }^{2}$ Beijing 101 High School, Beijing, China \\ Email:drzhaozhen@sina.com,profxiongwei@sina.com,joannafjx@sina.com
}

Received 14 July 2016; accepted 8 August 2016; published 11 August 2016

Copyright @ 2016 by authors and Scientific Research Publishing Inc.

This work is licensed under the Creative Commons Attribution International License (CC BY).

http://creativecommons.org/licenses/by/4.0/

(c) (i) Open Access

\begin{abstract}
China has been fast growing over past 30 years. Whether China could keep relatively high speed sustained growth is very important to the whole world. And it is worthwhile to analyze the reason to keep high speed sustained growth. The paper analyzes the total amount situation of Gross Domestic Product (GDP) of China as the second world economy entity. As a developing fast growing country, China has its own characteristics and also has big gap to the first world economy entity, the USA. With the rapid development of internet, the paper compares the traditional business model to future business model development. As a part of national strategies of China, internet is becoming one of the most important tools for both business increasing and marketing developing with its users fast growing. The relativity between internet and China economy is analyzed through related model. With internet plus time coming, China economy development will be related to internet tightly in current time and future.
\end{abstract}

\section{Keywords}

Impact, Strategy, Internet, Economy Development, Marketing, GDP

\section{Introduction}

In 2010, China surpassed Japan to become the second world economy entity based on total amount of Gross Domestic Product (GDP) [1]. It is a milestone to China. Besides that, the following question appears: could China catch up USA which is the first world economy entity? When and how can China make it happen? With the internet growing rapidly and deeply, could China make good use of it to realize economy mid-high and sustained growth in a long term? We can do some analyses briefly here through several aspects including historical data analysis, GDP total amount growth analysis, influence of internet to business development and industries analysis, etc. 


\section{Glance about China Economy in History}

In order to understand China economy in history, GDP situation and population percentage in the world could be as important parameters to show easily.

\subsection{China GDP Total Amount Percentage Proportion in the World Change Greatly in History}

Looking back to China over 2000 years' history, percentage proportion of GDP total amount in the world changes greatly in different dynasties. Qin Dynasty has no detail data. Han Dynasty was economic center in eastern world. Its GDP total amount percentage proportion could be compared with old Roman Empire. Tang Dynasty created the peak GDP total amount percentage proportion in the world at its time. Song Dynasty created highest GDP total amount percentage 80\% proportion in the world. Ming Dynasty GDP total amount percentage proportion began to decrease and re-grew at the beginning of Qing Dynasty then dropped quickly after 1840. With the PRC founded, China GDP total amount percentage proportion in the world resumed gradually and become the second economy entity now [2].

\subsection{China Population in History Rank Big Percentage Proportion in the World}

China population change in over 2000-year history has its own characteristics. From the century beginning 60 million to 1850430 million, total number only increased 7 times. Year of year (YOY) growth is only $0.1 \%$. The growth rate is quite low. There are many factors to affect population growth. These factors include natural geography surroundings, agricultural production, war, politic systems and traditional thinking and idioms etc. [3].

Although many factors could affect population growth, China population percentage in history occupies quite big. Except at the ending of Dong Han Dynasty below $10 \%$ as bottom, at other time the number is often above $20 \%$. Usually the percentage could occupy $30 \%$ roughly.

From the analysis above, China GDP total amount and population percentage proportion in the world in history could be showed in Table 1 [4]. Comparing to the peak time of China history, China has big room to increase on GDP percentage proportion in the world. Or China has big potential on economy development.

Table 1. China GDP total amount and population percentage proportion in the world in history.

\begin{tabular}{|c|c|c|c|}
\hline Time & GDP percentage in the world & GDP rank & Population percentage in the world \\
\hline Han Dynasty & $26 \%$ & 2 & $10 \%$ \\
\hline Tang Dynasty & $58 \%$ & 1 & $20 \%-30 \%$ \\
\hline 1000 & $22.70 \%$ & 2 & $20 \%-30 \%$ \\
\hline Song Dynasty(1095) & $80 \%$ & 1 & $20 \%-30 \%$ \\
\hline Ming Dynasty(1500 1600) & $25 \%-29 \%$ & 1 & $20 \%-30 \%$ \\
\hline Qing Dynasty(1700) & $22 \%$ & 2 & $20 \%-30 \%$ \\
\hline Qing Dynasty(1800) & $32 \%$ & 1 & $20 \%-30 \%$ \\
\hline Qing Dynasty(1870) & $17 \%$ & 2 & $20 \%-30 \%$ \\
\hline 1900 & $6 \%$ & & $20 \%-30 \%$ \\
\hline 1945 & $4 \%$ & & $20 \%-30 \%$ \\
\hline 1997 & $3.50 \%$ & & \\
\hline 2005 & $4.90 \%$ & 4 & $20.20 \%$ \\
\hline 2009 & $8 \%$ & 3 & $19.60 \%$ \\
\hline 2014 & $13.40 \%$ & 2 & $19 \%$ \\
\hline 2015 & $14 \%$ & 2 & $18.80 \%$ \\
\hline
\end{tabular}




\section{Does China Has Opportunity to Become First Economy Entity Based on GDP Total Amount Value}

According to the official data of China State Statistics Bureau (CSSB), China GDP is roughly 1110 billion USD in 2015. Based on International Monetary Fund (IMF) assumption, USA GDP is roughly 1784 billion USD in 2015. From these data, China and USA GDP could be assumed to calculate the trend development in the coming years.

\subsection{The Calculation Model to Compare China and USA GDP Trend Development}

To forecast the future economy trend, the model could be described as formula 1 [5].

$$
\mathrm{GDP}_{x}=\mathrm{GDP}_{B} \times(1+r)^{n}
$$

In the formula $1, \mathrm{GDP}_{x}$ is future year GDP number; $\mathrm{GDP}_{B}$ is basic GDP total amount value like 2015 country GDP total amount value; $r$ is average YOY growth rate of GDP; $n$ is year number or $x-1$.

If $\mathrm{GDP}_{\mathrm{B}}, \mathrm{r}$ and $\mathrm{n}$ could be known, after $\mathrm{n}$ year GDP of a country can be calculated.

\subsection{Time Calculation of China GDP Catching up USA GDP}

According to formula 1, China GDP growth forecast could be showed as formula 2.

$$
X=\text { ChinaGDP }_{2015} \times(1+\text { China GDP average YOY growth rate })^{n}
$$

In formula 2, $X$ is GDP value after n year from 2015; ChinaGDP 2015 is China GDP value of 2015; China GDP average YOY growth rate is future 10 to 15 year China GDP average YOY growth rate assumption; $n$ is year number.

As same USAGDP growth forecast could be showed as formula 3.

$$
Y=\operatorname{USAGDP}_{2015} \times(1+\text { USA GDP average YOY growth rate })^{m}
$$

In formula 3, $Y$ is GDP value after m year from 2015; USAGDP ${ }_{2015}$ is USA GDP value of 2015; USA GDP average YOY growth rate is future 10 to 15 year USA GDP average YOY growth rate assumption; $m$ is year number.

According to CSSB of China official data, the value of formula 2 could be set briefly as below.

ChinaGDP $_{2015}$ is 1110 billion USD. Based on Mr. Liu Shijin who is Deputy Director of China State Development Research Center announced assumption data, in coming 10 years China YOY GDP average growth rate is $6.2 \%$ [6]. According to data of Nomura announced and assumed, China YOY GDP average growth rate will down to 5\% after 10 years and will sustain this middle and high speed in a long time [7]. Thus China GDP average YOY growth rate is $6.2 \%$. Formula 2 could be described as formula 4 .

$$
\begin{gathered}
X=1110 \times(1+6.2 \%)^{n} \quad(\mathrm{n} \leq 10) \\
X=1110 \times(1+5 \%)^{n} \quad(\mathrm{n}>10)
\end{gathered}
$$

$X$ is China GDP value after $n$ year; $n$ is year number.

According to World Bank and American Standard \& Poor's forecast, USA GDP YOY average growth rate in future years is roughly $2.5 \%$. Thus formula 3 could be described as formula 5 .

$$
Y=1784 \times(1+2.5 \%)^{m}
$$

$Y$ is USA GDP value after $m$ year; $m$ is year number.

When China GDP catches up USA GDP in total amount, formula 4 should be equal to formula 5 . Or $X$ is equal to $Y$ and $n$ is equal to $m$. So the formula 4 and formula 5 is equal. Thus $n$ and $m$ could be calculated.

$$
n=m=15 \text {. }
$$

This means China needs another 15 year to catch up USA on GDP from now on. Or in 2030 roughly China 
GDP total amount value will catch up and even surpass USA GDP and become first economy entity at about 2584 billion USD.

If YOY worldwide GDP average growth rate is assumed 3\%, worldwide GDP will be 12,385 billion in 2030. The total amount value percentage proportion of China GDP will be $20.9 \%$ roughly in the world. It will be a reasonable number.

\section{Impact of Internet to Traditional Marketing Model in Business and Economy}

Through above analysis, China needs to increase 1.5 times GDP total amount value so as to catch up USA and become largest economy entity. In order to realize it, the economy of China needs to grow fast. Concretely speaking, business in China should be increased rapidly. Business growing has tight relationship with marketing. The key point of marketing to business development is making use of the speed of wideness of technique to access customers.

The basic internet structure appeared on 40 years ago, it gave us a business platform. On this platform, people could play game, go shopping, watch TV, make friends and do research etc. With internet, people have to do many reforms [8].

In the past a few years, internet as a new media which reflected very quickly and penetrated strongly leaded to bombed growth on marketing directly. Almost everyone who has Personal Computer (PC) could set up web station and promote brand. The relevant investment is almost zero. The game rule had been totally changed [9]. Now with the mobile phone widely used, mobile internet is developing rapidly.

Internet is becoming a marketing tool at our new time. It has brought us an unimaginable huge reform. In human history progressing, when the communication speed and wideness had tremendous and revolutionary progress, it would lead to a new height of marketing and business development. Internet time has surpassed any times of history. There is nothing like internet speed and wideness which could make us dizzy. And internet can be instant and global [10].

It is because internet almost could touch everyone and everywhere, the daily life of people and future will be affected greatly. Not only to the individual but also to the organization, environment, and family etc internet will bring many things to the human beings very much. Comparing to traditional marketing model, internet affects a lot in business and economy radically.

\section{Impact of Internet to General Business Model}

With the internet huge and rapid growth today, to some extent, the customers relevant to internet represent business new growth and development. The vendors or business sellers who get advantages on internet business model will win easily in business competition. So internet should be focused on future business.

\subsection{General Business Model Pattern}

The general business model pattern was described in Instant Leads (Brad Sugars, 2009). It is shown as Figure 1. The relevant explanation to general business model is showed as below [11].

\subsubsection{The Parameters Described in General Business Model}

More customers, more revenues and more profits are parameters to measure business commonly in our society today. However, if we analyze from Figure 1 carefully, it is easy to find that these key parameters-customers, revenue and profit do not exist in isolation. These parameters are only results that those factors affect them.

\subsubsection{The Factors Influenced to General Business Model Result}

Figure 1 has shown some factors effect to us. If we want to get more customers in business, we should increase both business leads and conversion rate. More leads, more potential customers and prospects in business. Conversion rate reflects the capability that we transfer potential business customers to definite purchasing customers. And the final number of customer is decided by both leads and conversion rate.

The revenue amount is relevant to purchasing customers. However, the turnover will be affected by each customer purchasing times in a period like a year and each time purchasing price. So the total revenue will be based on customer number and will be affected by number of transactions and selling price. 


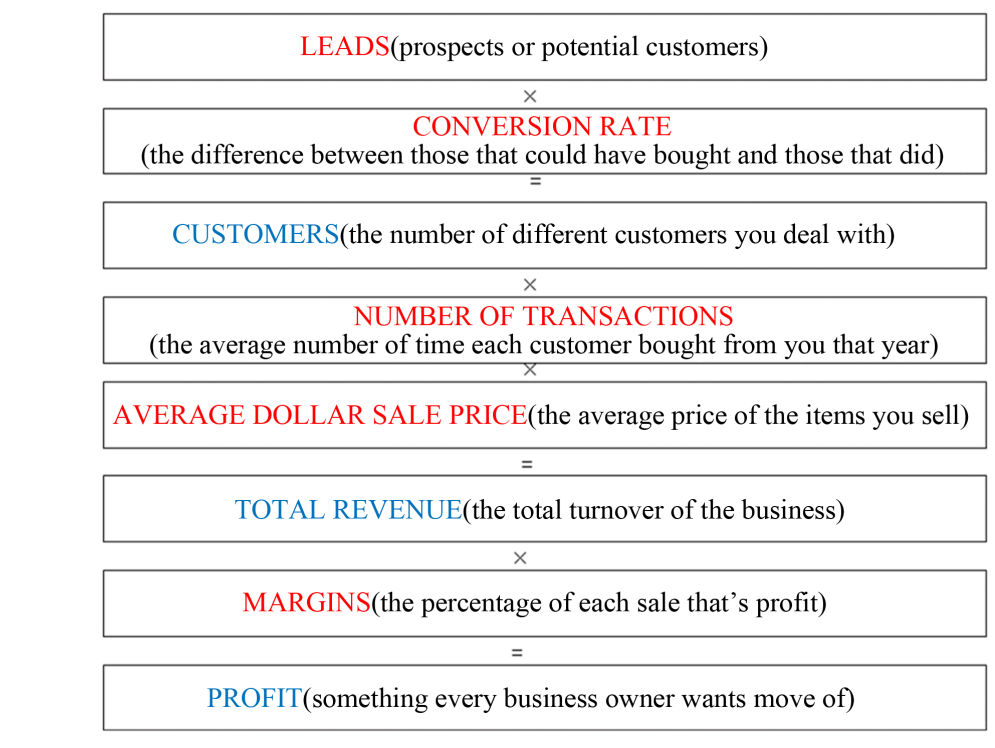

Figure 1. General business model pattern. Source: Instant leads (Brad sugars, 2009).

To the profit, it is easily understood that will be decided by margin percentage.

So we can easily find though business results could be described by customers, revenue and profit, the root factors include leads, conversion rate, number of transactions, average selling price and margin actually.

\subsection{Role of Internet in Business Development}

Today internet plus has become a part of national strategies in China. Internet user number is growing rapidly. Internet is affecting our business greatly and changing the weight portion in our business. And successful business development will be connected with the sustained influence trend of internet in the future. Here the relevant internet data of China will be analyzed as below.

\subsubsection{Fast Growing on Internet Users Leads to More Business Potential and Development}

At the end of 2015, global internet users surpassed 3.2 billion. And in China the number touched 668 million as Figure 2 shown [12]-[15].

It is showed that internet is widely used in China. In 2010, China internet penetration rate is 34.3\%. In 2015, the number grows to $48.6 \%$. With the fast growing of both internet access and users, it is easily to enlarge leads to various kinds business and strengthening the potential customer base in general business model. Based on it, successful business development could be expected. And it will affect China economy development further.

The E-commerce revenue growth trend displays positive relationship with online shopping people very well as Figure 3 [16].

During 2010 to 2015 period, online shopping people in China grew from 158 million to 413 million. The growth rate is over $150 \%$. However, the E-commerce revenue that they generated was increased from 4500 billion RMB to $16200 \mathrm{RMB}$. The growth rate is $260 \%$. The data showed internet is tightly related to business development in China. The revenue number is nearly $25 \%$ of China GDP number. It is showed that China economy is being influenced by internet plus business.

\subsubsection{Internet Also Affects Other Factors of General Business Model}

China mobile users' situation is showed in Figure 4 [17].

In 2015 China mobile users touched 1.3 billion. 0.9 billion of them used mobile internet. This is a great platform for both marketing development and business growth. Because these users could be touched anywhere easily.

With the internet leads base increase, marketing and promotion tools could be implemented. Since marketing tools can be easily and efficiently used through internet, it will be good to the conversion rate improvement in general business model. 


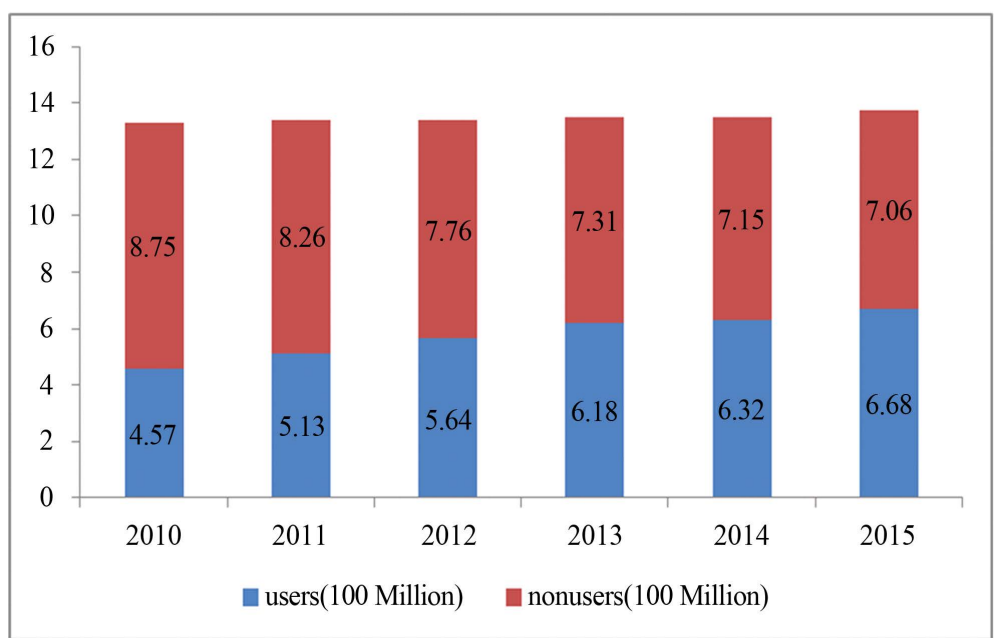

Figure 2. China internet user situation. Source: ICT indicators database.

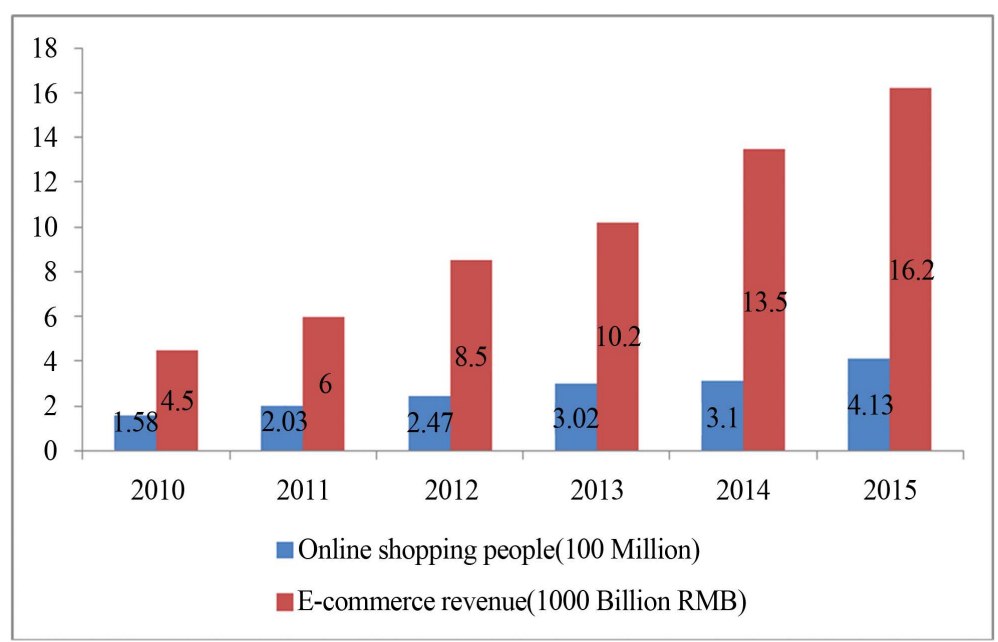

Figure 3. China E-commerce revenue. Source: China State Statistics Bureau Data.

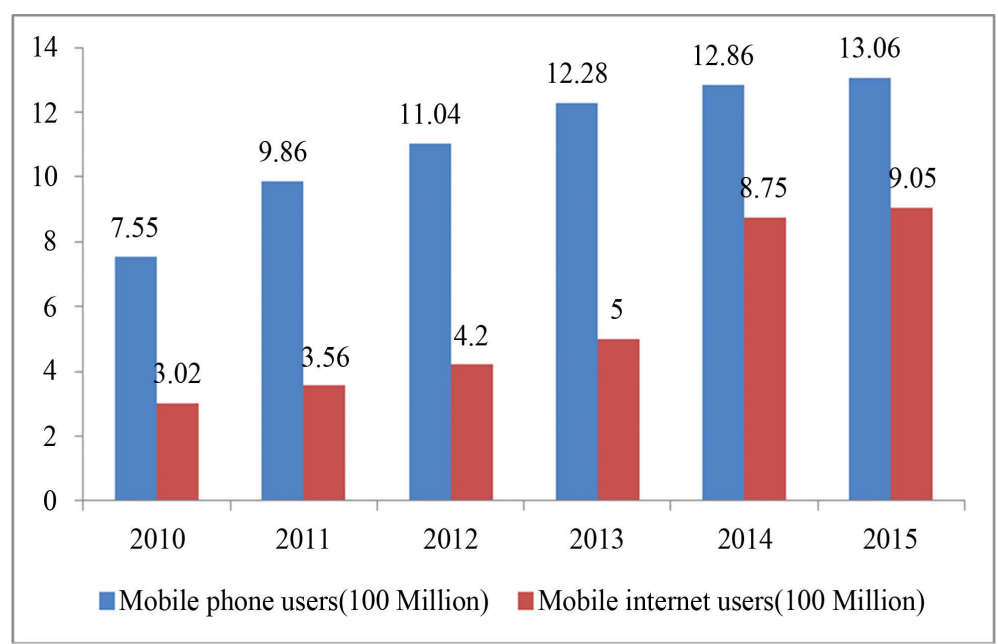

Figure 4. China mobile users situation. Source: China internet association data. 
Comparing to traditional selling tools, internet now becomes a simple and comfortable platform to do business and marketing promotion. Product introduction and promotion could be showed perfectly through internet and computer or mobile screen. Customers needn't arrive at the exchanging site. Depending on computer or mobile network, customers almost could exchange at home, office and everywhere. Since it is very convenient, the number of transactions could be improved easily in general business model. Because of the same reason, with the exchanging and marketing expense decrease, it will also be good to improve average selling price.

With more and more wide usage of internet, whether buyers and sellers could save much relevant cost like physical store, employee and rent for the offices, etc. This definitely could lead to the margin improvement in general business model. So the internet plays a very important part in successful business development.

\subsection{Relationship between China GDP Total Amount Growth and Internet Usage}

According to the data of China State Statistics Bureau and ICT announced, China GDP total amount and internet users' number are showed in Figure 5.

With the number of China internet users growing, China GDP total amount is growing. According to the statistics theory and correlation analysis of Karl Pearson, the relationship between China GDP total amount and internet users in China can be analyzed.

The relativity between China GDP total amount and internet users in China can be described as below:

$$
r=\left[\sum\left(x_{i}-X\right)\left(y_{i}-Y\right)\right] / \sqrt{\left[\sum\left(x_{i}-X\right)^{2} \sum\left(y_{i}-Y\right)^{2}\right]}
$$

$r$ is the correlation coefficient to describe relationship between China GDP total amount and internet users in China. $r>0$ means positive relativity; $r<0$ means negative relativity; $r=0$ means 0 relativity. $x_{i}$ is China GDP total amount and $i=1, \cdots, 6 ; y_{i}$ is number of internet users and $i=1, \cdots, 6 ; X$ is average China GDP total amount from 2010 to 2015. $Y$ is average number of internet users in China from 2010 to 2015.

$$
\text { Based on formula (6), } r=4.023 / 12.93=0.31>0
$$

So China GDP total amount has positive relativity with the number of internet users in China. That means the internet usage can be one of important factors which lead to China GDP total amount growth.

\section{Internet plus to China Economy and Business}

In internet plus time, many industries have relationship with internet and reform greatly. These changes affect China economy and business very much.

\subsection{Early Stage of Internet in China}

China economy development was not balanced in past. Although remote cities and countryside business grow

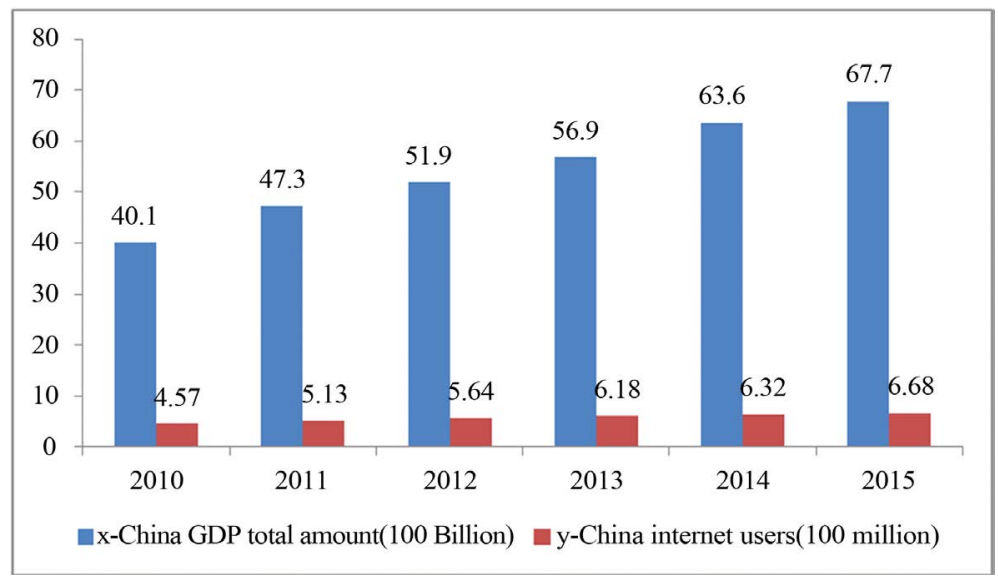

Figure 5. China GDP total amount and China internet users. Source: China state statistics bureau/ICT data. 
rapidly, the percentage is usually below $30 \%$ in whole business in China. But this business weight is relevant to over 500 remote cities and over 90\% Chinese population. It is easily found business cost is a big issue to any vendors in business development. So internet displays its advantage on this point. From wideness, speed, convenience and cost etc, internet is very effective and efficient.

B2B and B2C business model having been used in business development for a long time. Then some new business models are developing.

\subsubsection{C2C Business Model}

C2C means consumer to consumer. Internet can give buying and selling two sides an online platform. The trade can be processed conveniently.

\subsubsection{B2M Business Model}

B2M means business to manager. B2B, B2C and C2C business model treat customers object as consumers. But the customer object of B2M is enterprise or sales person relevant to products. For example, in China, the traditional internet user number is 140 million. However, to B2M business model, the number is 1400 million or whole Chinese. It is very different from other business model.

\subsubsection{B2A Business Model}

B2A means business to administrations or business between enterprise and government. Many government purchasing and IFB will use the business model.

\subsubsection{C2A Business Model}

C2A means consumer to administrations or business between individual and government. For example, individual uses internet to do taxation. It is the initial step to use the business model.

Whether what kind of business model we called in internet, the business currently has touched internet everywhere.

\subsection{Internet plus Time to Industries in China}

Internet has created a different environment for the marketing and business or economy. Internet has changed the past role of strategy and competition. Undoubtedly, profitability has decreased in different industries by appearance of internet. With current big data, cloud calculation and the combination with internet application, China has contributed four among the World's Top 10 Internet companies. In addition, the combination of internet and many traditional industries like finance, transportation, and service industries such as food \& beverage has enabled smoother communication, better experiences and rating systems for these industries and services [18].

Like internet plus traditional advertisement becoming Baidu, internet plus department store becoming JD and internet plus traditional market being Taobao, the combination of internet with different industries create more business opportunities and contribute much to China economy.

\subsubsection{Retail}

Through business model like C2C and B2C, the price of goods is very transparent. The cost of information got to end users could be decreased greatly. This leads to the real price range being got to everyone. The information of asymmetry like William Poundstone described in his priceless is difficult to appear in internet plus time [19]. Thus price will be synchronous through combination of online and offline. The product which has outstanding end user experience will take the cake. With big data application, the end user will get personal service.

Similarly WeChat E-commerce could also use this model. In China there are 400 to 500 million WeChat active users monthly [20]. The market is quite big.

\subsubsection{Wholesale}

Traditional wholesale business is usually limited by region. The resellers need to take the risk every time. With Alibaba B2B model appeared, the risk dropped to the lowest extent. Under the internet plus influence, B2B will be globalized totally. The trust issue in the past will be set up very well with time going. With internet growing to some extent, the resellers will disappear gradually. More and more business is going to change to B2C model. 


\subsubsection{Manufacturing}

The traditional manufacturing is not open. The manufacturer decided what kind of product being made. However, with the internet application, the customers have opportunity to participate in the loop of production. The product could be made as they want. The relevant business model is customer to business (C2B). As Kevin Kelly described in the technium, internet time will create huge strength [21]. The big scale advertisement and production time will be ended. Everyone will be designer, producer and decision maker.

\subsubsection{Advertisement}

Advertisement has entered accurate delivery time. In China, if anybody searches relevant key word of product on Baidu, Google or Taobao, the relevant product advertisement searched will appear when related alliance network station being entered. The advertisement in internet plus time has characteristics including accurate delivery and big data depended on.

\subsubsection{Journalism}

The traditional journalism is monopolized. The fact is difficult to release. With internet development, We-Media era is coming. Transparency is the characteristics of it. In China, more and more people of journalism move to We-Media work.

\subsubsection{Telecommunication}

With internet development, the link among people is very tight. Now people less and less rely on telephone and message. WiFi will be everywhere. People will enter internet of things (IOT) time. Telecom is not only among people but also between people and things, things and people and things and things. Now with light fidelity (Li-Fi) technique becoming mature, the telecommunication will be 100 times upgraded.

\subsubsection{Logistics}

In China, E-commerce development requires high quality of logistics including capability, responsibility and etc. Process of logistics will be enhanced very much under cruel competition.

\subsubsection{Hotel and Tourism}

In traditional business model, customers used to be cheated because of information unclear. Based on internet hotel and tourism in China could be evaluated in detail. The benefit of customers could be protected. On the other hand, based on big data analysis of internet, the preference of customers could be judged and served locally. The personal schedule and program could be supplied easily.

\subsubsection{Catering}

With E-commerce and mobile internet development, O2O is becoming a dominant way. Under this model, marketing and payment could be finished online. The relevant service and experience are offline. This model could be applied in many industries based on internet. In China catering industry, more and more local comments like dianping.com, fanqie.com and Taodiandian.com etc could be executed online. And the vendors could improve their service level by these online comments. Based on internet the competition will lead to good restaurant well known. The restaurants which utilize so called water army to promote will be damaged by several real comments. The catering will be influenced by transparent internet fairly.

\subsubsection{Finance}

Internet finance is a new kind of model based on payment, cloud calculation, social internet $\&$ search engine and APP etc internet tools. It is a kind of inclusive financial system. Comparing to traditional finance, it has many characteristics like strong transparency, high participation, good cooperation, low cost and easy operation etc. Unlike traditional business model displaying that $80 \%$ performance come from $20 \%$ products, long tail model can be explained to it. Only if both storage and channel are big enough, the pile-up of small \& tiny market could compete with main market. In fact long tail model needs two preconditions. One is low cost enough. The other is enough customers. The profit could be made easily because of two factors.

Peer-to-Pearleading (P2P) and Third-Party Payment developed very fast in China. The business is based on big data information processing. And foundation is cloud calculation. However, from the actual experience in 
China, the risk is quite high. Some cheating issues often happen. The restructure will happen quickly. Next step more and more high value business like automobile, estate and etc. will link with supply chain P2P tightly.

\subsubsection{Insurance}

In traditional model, there are so many tiers lead to unclear information. The insurance applicant often neglects the risk of product because of over packing. In China, the relationship is more important than product itself. However, with the internet plus era coming, the risk could be cut down. Based on big data, precise advertisement will be delivered.

\subsubsection{Heath care}

Internet plus health care industry is a typical $\mathrm{O} 2 \mathrm{O}$ model. To a patient, when he or she has disease, the evaluation of relevant doctor could be found and checked online. Through reliability of big data, the diagnosis could be completed on internet. The treatment and medicine could be realized transparently offline. Furthermore, people could do prevention and precaution through online including information sharing. The relevant layer treatments and payments could be handled offline. In future, with IOT development, everyone's habit, hobby and information will be stored on cloud. Precise judgment could be done by doctor online. This model also could be used to Chinese traditional treatment.

\subsubsection{Education}

Traditional model is an outstanding education model. In internet plus time, education means not only score. It will be full of personality education. Based on various characteristics of people, the relevant layer and class education could be selected and executed.

\subsubsection{TV, Film and Publishing}

TV industry has not been influenced very much in USA. This is because of the high quality of program and the traditional habit. However in China, the situation is totally different because of program quality. Thus people in China are not limited passively. Free selection through internet is possible and ongoing.

Similar situation happens in film and publishing industry. Personal request and high quality products will be the trend. Traditional high quality program including TV and Film maybe exist like some famous paper works. Low quality products and vendors cannot survive in the completion.

With the high technique development worldwide, the high technique products appear very fast. Especially in individual products aspect, new type with high feature, high speed and easy used products like mobile, TV and etc are changing our life and business very much. Through mobile, people could select and order customizing product and consume. In order to satisfy customer need, vendor will change process, culture, organization even human structure.

Like long tail model, the needs of tail part will be satisfied in TV, Film and Publishing etc relevant industries. For example, with high technique development, the CPU capability after 30 years will be 1 million times now. So the development and progress of high technique will lead to the quick growth of internet plus many industries bundled C2B model. And with a mobile, people could enjoy many entertainments like game, TV, chat, watching, reading, education and etc. Just like LeTV describing, intelligent industry chain with platform, content, terminal and application feature will be pursued and realized [22].

In the end, to those monopoly industries, with internet development information will not be filtered gradually. All ice mountains will appear because of internet. The country, nation and religion could be neglected in front of information based on internet.

\subsection{Impact of Internet to Successful Business and Economy Development}

The fact is that internet penetration grows very fast now especially with mobile internet application. In 2015, China internet video users hit 461 million. 354 million of them were mobile customers. $25.6 \%$ of mobile video users are below 20 years old [23]. Some data could support the situation in China as below.

\subsubsection{Internet Business Development Has Great Potential}

From Figure 3 above, the E-commerce revenue in 2015 is roughly 16,200 billion RMB. This is a very huge market. And the over $20 \%$ year of year growth rate will attract many enterprises. For example, Alibaba which is 
the biggest internet company in China. When Aliaba went to IPO in New York on September 19, 2014, on same day Alibaba ranked No. 2 largest internet company [24]. On November 11, 2015 1688.com revenue is nearly 14 billion USD. These data display that the internet will deeply influence us whether in daily life or business development in future.

\subsubsection{Leads and Potential Customer Management}

Customer relationship management or CRM is widely used in business management. In general business model, we can use 1 to 1 management method and try our best to meet customer need [25]. However, with huge number of customers and different needs at internet plus time, it is really a problem we need to solve. Recently the CRM solution based on sales cloud of salesforce.com had made great progress in this area. Over 100,000 enterprises select this CRM solution to manage their customers and business development.

\subsubsection{To Improve Business Management through Internet}

In general business model, MBO or management by objective method is often used. When setting up business objective, SMART method is often used. The objective is specific, measurable, achievable, relevant and time setting [26]. But based on the characteristics of internet, business management whatever selling process, marketing, product, SCM and service etc should be improved. Now with the Cloud technology application, more and more vendors and business partners use the relevant solution from like IBM which is cloud platform customers service solution supplier to analyze customers' activities and intents in digital. For example, through internet data, the customer habit and intent could be recognized and analyzed. Through internet, the relevant ads and marketing tools could be displayed to special customer. And the willing to purchase could be improved through this kind of special information delivered. Thus the customers could be served more efficiently and effectively. It will lead to better business result directly.

\subsubsection{Great Relevant Business Opportunities}

According to the data of China, current China E-commerce yearly revenue is roughly 16,200 billion RMB. If $1 \%$ service charge could be executed, only this business will be 162 billion RMB or nearly 25 billion dollars yearly not alone other business. So it is a big and with fast growing potential market. From June $1^{\text {st }} 2015$, China government opened Unipay relevant business. This will improve E-commerce development in China.

In China, internet retail business was quite small with revenue often 100-dollar below in past. But now many big amount commodities like cars, house and etc. is starting to exchange through internet. The successful business development through internet will have big potential in China indeed.

\subsection{Other Relevant to Internet plus}

\subsubsection{Cost is Key Point of Internet plus Related Industries}

In the mobile internet era, new customers, new market and new value could be created through internet plus new channels, new ways and new applications. However, the relevant management key point is cost. Free is only one marketing way in a short time. For a long term, free would be an issue to any vendors.

\subsubsection{Internet plus is Not Everything}

Internet has many advantages including good interface, near customers need, fast upgrade speed, precise marketing, quick response to customer, low cost, online service and etc. However, internet could not replace product innovation, technique research and development, product production and supply chain management etc. Internet finance also could not change the core issue risk control [27]. So internet is not everything. Internet is only one of tools to improve marketing, business and economy.

\section{Summary}

\subsection{Limitations of the Research}

Considering large population of China, GDP per capita is backward in the world. In the paper, only GDP total amount not per capita growth is taken. Hence, the findings of the impact of internet plus on per capita growth may not be the same. Currently only China GDP total amount with the influence of internet plus is touched and discussed. 


\subsection{Conclusions}

In conclusion, internet is changing a lot to the world. The most valuable point of internet is not that internet creates a lot of new things. The key point is through internet people could dig again to all current industries. Based on the transparent information shared and the big data integrated, the relevant resources could be utilized to the maximum extent. With relatively high speed growth rate to China economy today, internet gives people a wide, efficient and productive platform in both business and daily life.

Though China Per Capita GDP is not high, with big population and relatively high sustained YOY growth rate on economy China GDP total amount value will increase very quickly. To many aspects of economy, the development of business will be relevant to internet plus. Internet plus time will play very important part in successful China economy development. With internet plus time development and it being a part of sustained national strategy, China will be the first economy entity in near future.

\section{References}

[1] International Monetary Fund (2011) World GDP Report of 2010.

[2] http://tieba.baidu.com/p/3415651507

[3] http://bbs.tiexue.net/post_3402271_1.html. 2015-07-28

[4] http://www.360doc.com/content/15/0902/08/4763469 496393023.shtml

[5] Mawson, P. (2002) Measuring Economic Growth in New Zealand, the New Zealand Treasury. Working Paper 02/14, p. 5.

[6] http://www.ce.cn

[7] http://www.diyitui.com

[8] Michael, J. (2002) Cunningham, E-Business. Capstone Publishing, London.

[9] Mariotti, J. (2003) Brands and Branding. Shanghai Far-East Press, Shanghai.

[10] Mariotti, J. (2002) Marketing. Shanghai Far-East Press, Shanghai.

[11] Sugars, B. (2006) Instant Leads. McGraw Hill, Inc., New York.

[12] (2014) ITU World Telecommunication/ICT Indicators Database.

[13] Lei, N. (2011) The Link CEIBS. Volume 2, CEIBS, Shanghai.

[14] (2014) Chinese Payment and Settlement Industry Operation Report.

[15] China Internet Network Information Center (CNNIC) (2015) Statistical Report on Internet Development in China.

[16] State Statistics Bureau of PRC (2016) E-Commerce Report.

[17] China Internet Association (2016) Report on 2015 China Internet Industry Summary and 2016 Development Trend.

[18] Zhe, F. (2015) Creating Value by Connecting People. The LINK, 4, 58-61.

[19] Poundstone, W. (2011) Priceless. Sino-Culture Press, Beijing.

[20] Kaige, C. (2014) Worry of Wechat E-Commerce: O2O or Platform. IT Time Weekly, 19, 37-38.

[21] Kelly, K. (2012) The Technium. Electronic Industry Press, Beijing.

[22] Li, X.R. (2014) LeTV CEO Jia Yaoting. IT Time Weekly, 21, 31-35.

[23] CNNIC (2015) Statistics Report of 36th China Internet Development Situation.

[24] Jian, C. (2014) Alibaba IPO in New York. IT Time Weekly, 305, 14.

[25] Jay, R. (2003) Customers. Shanghai Far-East Press, Shanghai.

[26] Tang, G.L., Gao, C. and Lu, C. (2010) CEO Planning and Budget System. Peking University Press, Beijing.

[27] Yang, Y.Q. (2014) Both Internet and Honesty Could Become Increase Engine of Enterprise. IT Time Weekly, 17, 13. 


\section{Submit or recommend next manuscript to SCIRP and we will provide best service for you:}

Accepting pre-submission inquiries through Email, Facebook, LinkedIn, Twitter, etc.

A wide selection of journals (inclusive of 9 subjects, more than 200 journals)

Providing 24-hour high-quality service

User-friendly online submission system

Fair and swift peer-review system

Efficient typesetting and proofreading procedure

Display of the result of downloads and visits, as well as the number of cited articles

Maximum dissemination of your research work

Submit your manuscript at: http://papersubmission.scirp.org/ 